\title{
The effect of low doses of betaine on plasma homocysteine in healthy volunteers
}

\author{
Georg Alfthan ${ }^{1 *}$, Kaisa Tapani ${ }^{4}$, Katja Nissinen ${ }^{2}$, Janna Saarela ${ }^{3}$ and Antti Aro ${ }^{1}$ \\ Departments of ${ }^{1}$ Health and Functional Capacity, \\ ${ }^{2}$ Epidemiology and Health Promotion and \\ ${ }^{3}$ Molecular Medicine, National Public Health Institute (KTL) Helsinki, Finland \\ ${ }^{4}$ Oy Sinebrychoff Ab, Kerava, Finland
}

(Received 9 February 2004 - Revised 21 June 2004 - Accepted 1 July 2004)

\begin{abstract}
Homocysteine is a risk factor for vascular diseases, and lowering of plasma total homocysteine (tHcy) may be beneficial for health. Homocysteine can be remethylated to methionine by betaine-homocysteine methyltransferase using betaine $(2(N, N, N$-trimethyl)glycine $)$ as methyl donor. A dose of $6 \mathrm{~g}$ betaine/d has been used in the treatment of homocystinuria, but data on the dose-response are scarce. Thirty-four healthy men and women were supplied with doses of 1,3 and $6 \mathrm{~g}$ betaine and then with $6 \mathrm{~g}$ betaine $+1 \mathrm{mg}$ folic acid for four consecutive 1 -week periods. The mean plasma tHcy concentration decreased by 1.1 (NS), 10.0 and $14.0 \%(P<0.001)$ after supplementation with 1,3 and $6 \mathrm{~g}$ betaine respectively. A further decrease in plasma tHcy by $5 \%(P<0 \cdot 01)$ was achieved by combining $1 \mathrm{mg}$ folic acid with the $6 \mathrm{~g}$ betaine dose. Plasma betaine increased from 31 (SD 13) to 255 (SD 136) $\mu \mathrm{mol} / \mathrm{l}$ in a dose-dependent manner $\left(R^{2}\right.$ 0.97). We conclude that plasma tHcy is lowered rapidly and significantly by 3 or $6 \mathrm{~g}$ betaine/d in healthy men and women.
\end{abstract}

Betaine: Homocysteine: Dose-response: Folic acid

Homocystinuria is a rare inherited disease in which homocysteine accumulates in high concentrations in the body (Mudd et al. 1995). The much more common state, mild hyperhomocysteinemia, is considered to be a risk factor for vascular diseases (Eikelboom et al. 1999); lowering plasma total Hcy concentration may thus be beneficial for health. Plasma total homocysteine (tHcy) is determined by intake of B-group vitamins, and by lifestyle and genetic factors. It has been shown convincingly in clinical trials that a moderate dose of folic acid lowers plasma tHcy to normal levels in healthy and in mildly hyperhomocysteinemic subjects (Homocysteine Lowering Trialists' Collaboration, 1998; Brouwer et al. 1999). Homocysteine may undergo transsulfuration to cysteine in a reaction requiring pyridoxine as cofactor and transmethylation to methionine by two different reactions: one requiring both 5-methyltetrahydrofolate and methylcobalamin, the other requiring betaine $(2(N, N, N$-trimethyl)glycine $)$ from catalysis by betaine-homocysteine methyltransferase (Mudd et al. 1995). The common polymorphism C677T, which reduces the activity of the enzyme methylenetetrahydrofolate reductase, is associated with approximately $40 \%$ higher plasma tHcy in carriers of the TT genotype compared with those with the wildtype (CC) (Gudnason et al. 1998).

Oral betaine has been used in addition to B-group vitamins in the treatment of homocystinuria since the early 1950s (Wilcken et al. 1983). The doses have varied between treated patients and the effects have not been well documented. Studies on the pharmacokinetics of betaine in patients with homocystinuria and in healthy adults have only recently been reported (Matthews et al. 2002; Schwahn et al. 2003). However, data on the doseresponse of betaine on plasma tHcy has not been available. The aim of the present study was to find the effect of graded doses of betaine on plasma tHcy concentration.

\section{Materials and methods}

\section{Subjects}

Adult volunteers (eleven men and twenty-four women) were enrolled from the staff of a brewery (Oy Sinebrychoff $A b$, Kerava, Finland). They were apparently healthy and had normal serum lipids, alanine aminotransferase, $\gamma$-glutamyltransferase and creatinine levels. One female subject discontinued the study after 2 weeks due to an intervening illness unrelated to the study. Her data were omitted from the calculations. The subjects gave their written consent and the study plan was approved by the local Ethics Committee.

\section{Study design}

During the first week the subjects received $1 \mathrm{~g}$ anhydrous betaine (Finnfeeds, Kantvik, Finland)/d dissolved in

\footnotetext{
Abbreviation: tHcy, total homocysteine.

* Corresponding author: Dr Georg Alfthan, fax + 3589 47448695, email georg.alfthan@ktl.fi
} 
$200 \mathrm{ml}$ mineral water. The drink was consumed during working hours. After 1 week the dose of betaine was increased to $3 \mathrm{~g} / \mathrm{d}$ and in the beginning of the third week to $6 \mathrm{~g} / \mathrm{d}$. During the fourth week the subjects continued to receive $6 \mathrm{~g}$ betaine/d and received in addition $1 \mathrm{mg}$ folic acid (Folvite ${ }^{\circledR}$; Wyeth Lederle, Nordiska AB, Solna, Sweden)/d. The 1-week periods on each dose of betaine were chosen on basis of a pilot study performed on six healthy subjects consuming $6 \mathrm{~g}$ betaine/d for $8 \mathrm{~d}$. Their plasma tHcy concentrations reached a plateau in $5 \mathrm{~d}$ with no further reduction thereafter.

\section{Blood samples and assessment of dietary intake}

Fasting venous samples were drawn into EDTA-containing vacuum tubes between 08.00 and 09.00 hours 7 weeks before baseline, at baseline, at the end of each intervention week and 3 weeks post-supplementation. The plasma was separated within $1 \mathrm{~h}$ and stored at $-70^{\circ} \mathrm{C}$ until analysed. One tube of whole blood was reserved for isolation of DNA.

During the study the subjects adhered to a low-folate diet in order to reduce fluctuations in folate intake. Two subjects regularly took B-group vitamin supplements: they were asked to discontinue their use 7 weeks before the intervention. On weekdays the subjects consumed their lunch at the same worksite cafeteria and during the weekends and the evenings they were instructed to avoid abundant consumption of fruits and vegetables. On each intervention week they kept food records during one weekday and one weekend day. The records were returned weekly and checked by a nutritionist. The nutrient intakes were calculated using the Fineli ${ }^{\circledR}$ food composition database of the National Public Health Institute (Ovaskainen, 2001).

\section{Chemical methods}

Plasma folate and cyanocobalamin were determined by ion-capture immunometric methods (IMX; Abbott Laboratories, IL, USA), betaine by HPLC (Laryea et al. 1998) and tHyc by 7-benzo-2-oxa-1,3-diazole-4-sulfonic acid (SBDF) reagent and HPLC separation according to Ubbink et al. (1991) with minor modifications (Knekt et al. 2001). The precision for tHcy between series ( $n$ 6) was $5.5 \%$ and the mean bias was $-4.0 \%$ in a quality assurance programme (Möller et al. 1999). DNA was extracted by a standard method (Bell et al. 1981). The methylenetetrahydrofolate reductase genotypes were analysed as described previously (Alfthan et al. 2003).

\section{Statistical methods}

The mean values between doses were tested for difference by the Wilcoxon signed ranks test, and mean values between genders by $t$ test, linear regression and Spearman correlations using SPSS (version 10.0; SPSS Inc., Chicago, IL, USA).

\section{Results}

The characteristics and baseline data of the subjects are shown in Table 1. Plasma HDL-cholesterol and tHcy differed significantly between men and women. There were
Table 1. Characteristics of subjects at baseline†

(Mean values and standard deviations)

\begin{tabular}{|c|c|c|c|c|}
\hline & \multicolumn{2}{|c|}{ Men } & \multicolumn{2}{|c|}{ Women } \\
\hline & Mean & SD & Mean & SD \\
\hline Gender $(n)$ & 11 & & 23 & \\
\hline Age (years) & 46.9 & $10 \cdot 7$ & $41 \cdot 7$ & $8 \cdot 8$ \\
\hline BMI $\left(\mathrm{kg} / \mathrm{m}^{2}\right)$ & $25 \cdot 2$ & 4.3 & $25 \cdot 0$ & $3 \cdot 2$ \\
\hline $\begin{array}{l}\text { Serum cholesterol } \\
(\mathrm{mmol} / \mathrm{l})\end{array}$ & 5.57 & 0.89 & $5 \cdot 35$ & 0.86 \\
\hline HDL-cholesterol (mmol/l) & $1 \cdot 18$ & 0.31 & $1 \cdot 50^{*}$ & 0.38 \\
\hline Smoking $(n)$ & 2 & & 2 & \\
\hline Plasma betaine $(\mu \mathrm{mol} / \mathrm{l})$ & 38.5 & $16 \cdot 6$ & $31 \cdot 4$ & $13 \cdot 9$ \\
\hline Plasma tHcy $(\mu \mathrm{mol} / \mathrm{l})$ & $13 \cdot 2$ & $4 \cdot 6$ & $10 \cdot 4^{*}$ & $2 \cdot 7$ \\
\hline Plasma folate $(\mathrm{nmol} / \mathrm{l})$ & $11 \cdot 2$ & 3.9 & $13 \cdot 7$ & $5 \cdot 4$ \\
\hline $\begin{array}{l}\text { Plasma cyanocobalamin } \\
(\mathrm{pmol} / \mathrm{l})\end{array}$ & 509 & 155 & 489 & 137 \\
\hline
\end{tabular}

tHcy, total homocysteine.

Mean values were significantly different from those of men: ${ }^{*} P<0.05$.

† Methylenetetrahydrofolate reductase genotype for all subjects (\%): CC $65 \cdot 7$, CT $28 \cdot 6$, TT $5 \cdot 7$.

two homozygotes for the methylenetetrahydrofolate reductase TT genotype, both male subjects.

The mean intakes $(2 \mathrm{~d})$ of nutrients during the baseline and each intervention week are shown for men and women separately in Table 2. The intake of folate from the diet did not change significantly in men or women during the four intervention weeks. The intake of energy was significantly lower $(P<0.05)$ than the baseline value during weeks 1 and 2 for women; pyridoxine concentration during week 2 was significantly lower $(P<0.05)$ than the baseline value for women; for men all nutrients remained unaffected.

The mean plasma betaine concentration ( $\mu \mathrm{mol} / \mathrm{l})$ increased from the baseline value of 31.4 (SD 13.6) to 52.5 (SD 26.5) (67\%) after $1 \mathrm{~g}$ betaine/d, to 109 (SD 41) $(247 \%)$ after $3 \mathrm{~g} / \mathrm{d}$ and to 255 (SD 136) $(712 \%)$ after $6 \mathrm{~g}$ betaine/d (Fig. 1). At no sampling point did the mean values differ between men and women. A second week on $6 \mathrm{~g}$ betaine/d did not further increase plasma betaine concentration. The increase in plasma betaine was dose-dependent $\left(R^{2}\right.$ 0.97). The mean betaine concentration had returned to baseline values 3 weeks post-supplementation.

The mean plasma tHcy concentrations before, during and after supplementation are shown separately for men and women in Fig. 2. The mean values for men and women differed at all points $(P<0 \cdot 05)$ except at the post-supplementation period. The mean plasma tHcy concentration in men and women combined (11.3 (SD 3.6) $\mu \mathrm{mol} / \mathrm{l})$ decreased after $7 \mathrm{~d}$ of $1 \mathrm{~g}$ betaine $/ \mathrm{d}(-1.1 \%, 0.42 \mu \mathrm{mol} / \mathrm{l}$; NS), $3 \mathrm{~g}$ betaine/d $(-10.4 \%, 1.3 \mu \mathrm{mol} / 1, P<0.001)$ and $6 \mathrm{~g}$ betaine/ $\mathrm{d}(-14.2 \%, 1.8 \mu \mathrm{mol} / \mathrm{l} ; P<0.001 \%)$ compared with baseline values (Fig. 3). The combined supplementation of $6 \mathrm{~g}$ betaine $+1 \mathrm{mg}$ folic acid/d resulted in a further decrease of $5.1 \%(-0.63 \mu \mathrm{mol} / \mathrm{l} ; P<0.01)$ in tHcy concentration.

There were six subjects (three women and three men, two of whom were homozygotes for the $\mathrm{T}$ allele of methylenetetrahydrofolate reductase) who at baseline had a plasma tHcy value $>14 \mu \mathrm{mol} / \mathrm{l}$ (mean $17 \cdot 3$ (SD 4.3) $\mu \mathrm{mol} / \mathrm{l}$; mean plasma folate 6.8 (SD 1.5) nmol/l). As expected, they benefited the most from betaine (Fig. 3). After the 
Table 2. The intake of nutrients of men and women during baseline and the intervention weeks $†$ (Mean values with their standard deviations)

\begin{tabular}{|c|c|c|c|c|c|c|c|c|c|c|}
\hline \multirow{2}{*}{ Week... } & \multicolumn{2}{|c|}{0} & \multicolumn{2}{|c|}{1} & \multicolumn{2}{|c|}{2} & \multicolumn{2}{|c|}{3} & \multicolumn{2}{|c|}{4} \\
\hline & Mean & SD & Mean & SD & Mean & SD & Mean & SD & Mean & SD \\
\hline Energy (MJ) & $10 \cdot 5$ & 2.66 & $9 \cdot 48$ & $4 \cdot 29$ & $8 \cdot 73$ & 3.59 & 9.95 & $4 \cdot 47$ & $11 \cdot 2$ & 3.6 \\
\hline Carbohydrate (\% energy) & $44 \cdot 1$ & $14 \cdot 8$ & $45 \cdot 2$ & $11 \cdot 8$ & $42 \cdot 8$ & 11 & $44 \cdot 7$ & 9 & $40 \cdot 8$ & $10 \cdot 9$ \\
\hline Fat (\% energy) & $35 \cdot 1$ & 11.9 & $34 \cdot 3$ & $9 \cdot 3$ & $34 \cdot 8$ & $8 \cdot 6$ & $35 \cdot 7$ & $7 \cdot 28$ & 33.7 & $8 \cdot 77$ \\
\hline Folate $(\mu \mathrm{g})$ & 259 & $90 \cdot 8$ & 246 & 128 & 247 & 114 & 286 & 156 & 280 & 88 \\
\hline Pyridoxine $(\mathrm{mg})$ & 2.08 & $1 \cdot 12$ & 1.99 & 1.56 & 2.02 & 1.06 & $2 \cdot 36$ & 1.41 & 2.43 & $1 \cdot 11$ \\
\hline Riboflavin (mg) & $1 \cdot 8$ & 0.4 & 1.9 & 0.8 & $1 \cdot 7$ & 0.7 & $2 \cdot 1$ & $1 \cdot 0$ & $2 \cdot 2$ & $1 \cdot 2$ \\
\hline \multicolumn{11}{|l|}{ Women ( $n$ 23) } \\
\hline Energy (MJ) & $7 \cdot 83$ & 2.47 & $6 \cdot 27^{*}$ & 1.92 & $6 \cdot 05^{\star}$ & 1.67 & $6 \cdot 35$ & $2 \cdot 12$ & $8 \cdot 33$ & 2.55 \\
\hline Carbohydrate (\% energy) & 43.7 & $11 \cdot 8$ & $45 \cdot 7$ & $9 \cdot 23$ & 46.5 & 8.08 & $44 \cdot 7$ & $10 \cdot 6$ & $41 \cdot 0$ & 9.35 \\
\hline Fat (\% energy) & $35 \cdot 3$ & 8.94 & 35.5 & $7 \cdot 5$ & $34 \cdot 8$ & 6.49 & $37 \cdot 2$ & $10 \cdot 2$ & 34.9 & $9 \cdot 22$ \\
\hline Folate $(\mu \mathrm{g})$ & 213 & 94.5 & 200 & 103 & 188 & $76 \cdot 2$ & 225 & 152 & 240 & 162 \\
\hline Cyanocobalamin $(\mu \mathrm{g})$ & $6 \cdot 34$ & 8.46 & $5 \cdot 65$ & 5.59 & 3.52 & $2 \cdot \overline{4}$ & $6 \cdot 45$ & $9 \cdot 38$ & $5 \cdot 76$ & $6 \cdot 47$ \\
\hline Riboflavin (mg) & 1.5 & 0.7 & $1 \cdot 2$ & 0.5 & 1.1 & 0.5 & 1.4 & 0.6 & 1.4 & 0.7 \\
\hline
\end{tabular}

Mean values were significantly different from those at baseline (week 0 ): ${ }^{*} P<0.05$.

†For details of subjects and procedures, see Table 1 and p. 665.

doses of 1,3 and $6 \mathrm{~g}$ betaine/d their mean plasma tHcy decreased by $-11.8 \%(2.2 \mu \mathrm{mol} / \mathrm{l}),-15.4 \%(2.6 \mu \mathrm{mol} / \mathrm{l}$, NS) and $-21.9 \%(3.9 \mu \mathrm{mol} / 1, P<0.05)$ respectively, with a further reduction of $-6.7 \%(0.9 \mu \mathrm{mol} / 1, P<0.05)$ after the additional folic acid.

The mean plasma folate concentration decreased $(P<0 \cdot 01)$ in both men and women after the first week on supplementation by 28 and $23 \%$ respectively, but returned to baseline values for the next 2 weeks. After week 4 , when the subjects were supplemented with betaine + folic acid, the mean plasma folate concentration increased by $59 \%$ in men and $41 \%$ in women $(P<0.001)$ and returned to baseline 3 weeks later. Plasma cyanocobalamin remained unaffected during the whole intervention.

\section{Correlation between plasma variables}

Plasma tHcy was significantly $(P<0.05)$ associated with plasma folate at all time points $(r 0.35$ to $-0 \cdot 66)$, but no correlations were found with plasma betaine or cyanocobalamin at any time point.

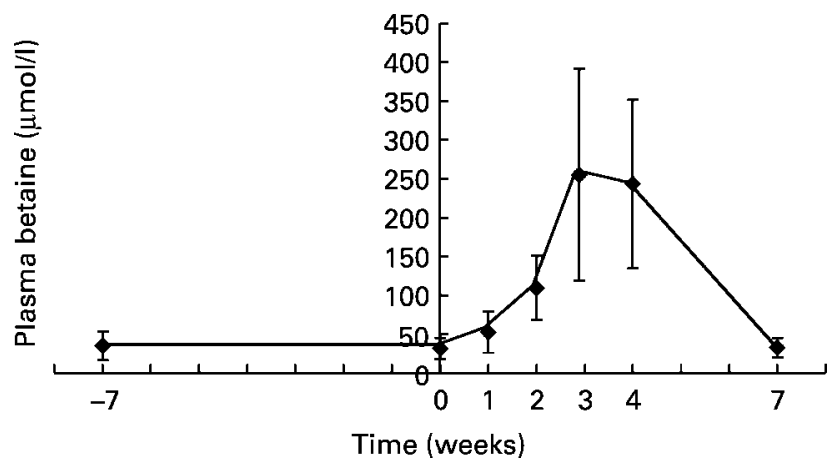

Fig. 1. Plasma betaine concentration of subjects ( $n 34)$ after consumption of 1,3 and $6 \mathrm{~g}$ betaine/d and $6 \mathrm{~g}$ of betaine $+1 \mathrm{mg}$ folic $\mathrm{acid} / \mathrm{d}$ (each dose for 1 week). For details of subjects and procedures, see Table 1 and p. 665. Values are means with standard deviations shown by vertical bars.

\section{Discussion}

Oral dosing with betaine in healthy subjects resulted in a statistically significant lowering of plasma tHcy $(P<0.001)$. The dose of $6 \mathrm{~g}$ betaine/d resulted in slightly lower efficacy in terms of percentage change per $g$ betaine compared with $3 \mathrm{~g} / \mathrm{d}$ ( 2.4 v. $3.4 \%$ respectively). The duration of the study per dose was only 1 week, but according to our pilot study this was sufficient to reach a maximal response. However, the response was transient, as 3 weeks after supplementation plasma tHcy had returned to baseline values.

In a smaller study from the Netherlands also on healthy subjects, Brouwer et al. (2000) reported that $6 \mathrm{~g}$ betaine/d lowered plasma tHcy by $8 \%$ in 2 weeks, a similar value $(9 \%)$ to that which was found in a study on obese subjects ( $n$ 42) who took $6 \mathrm{~g}$ betaine/d for 12 weeks (Schwab et al. 2002). In a recent study by Olthof et al. (2003), four groups

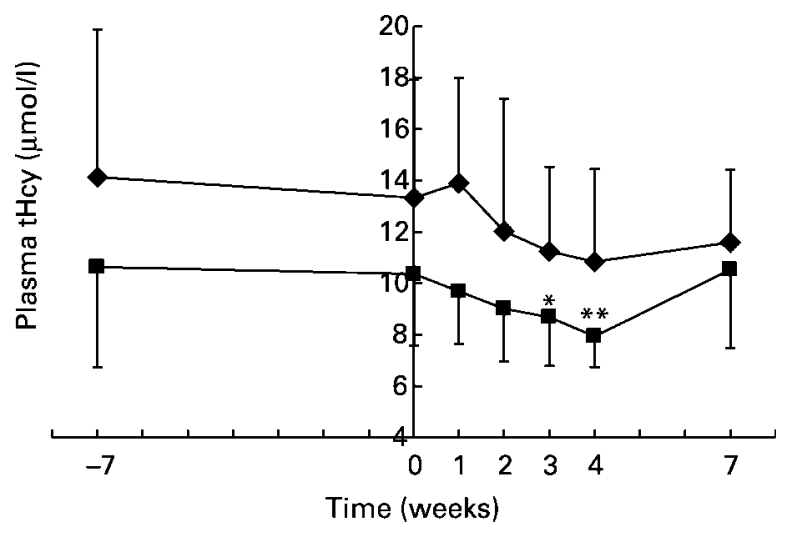

Fig. 2. Plasma total homocysteine (tHcy) concentration of men $(n 11 ; \diamond)$ and women $(n 23 ; \mathbf{\square})$ after consumption of 1 (week 1$), 3$ (week 2) and 6 (week 3 ) g betaine/d and $6 \mathrm{~g}$ betaine $+1 \mathrm{mg}$ folic acid/d (week 4) (each dose for 1 week). For details of subjects and procedures, see Table 1 and p. 665. Values are means with standard deviations shown by vertical bars. Mean values were significantly different from those at baseline: ${ }^{\star} P<0.05,{ }^{\star \star} P<0.01$. 


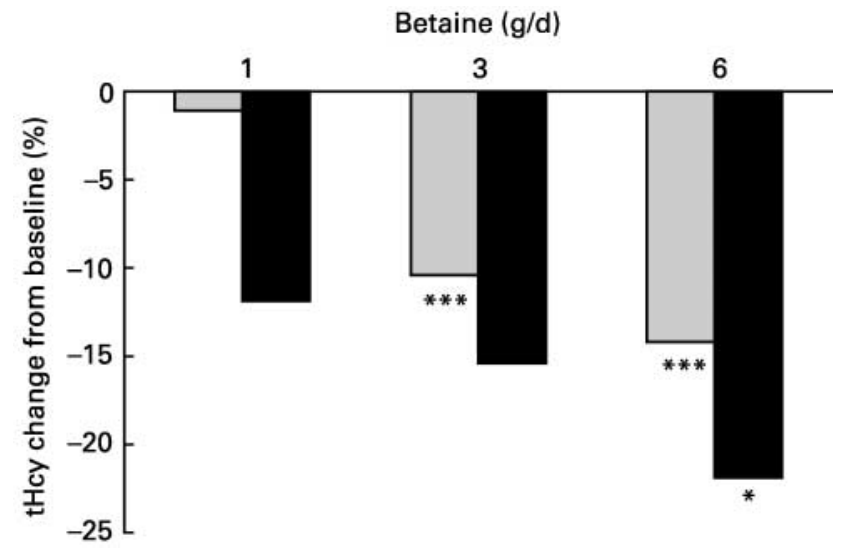

Fig. 3. Mean changes in plasma total homocysteine (tHcy) concentration after consumption of 1,3 and $6 \mathrm{~g}$ betaine/d (each dose for 1 week) in all subjects ( $n 34 ; \quad)$ and in subjects with a tHcy concentration $>14 \mu \mathrm{mol} / \mathrm{l}$ at baseline $(n 6 ; \mathbf{\square})$. For details of subjects and procedures, see Table 1 and p. 665. Mean values were significantly different from those at baseline: ${ }^{\star} P<0.05,{ }^{* \star} P<0.001$.

(nineteen per group) of healthy adults were given $1 \cdot 5,3 \cdot 0$ or $6.0 \mathrm{~g}$ betaine or placebo twice per $\mathrm{d}$ for 6 weeks. Compared with the placebo group after 6 weeks, plasma tHcy concentration decreased 12,15 and $20 \%$ respectively. However, even after 2 weeks on betaine the plasma tHcy-lowering effect was maximal on all doses. This finding, together with that from our pilot study, suggests that betaine lowers plasma tHcy almost immediately (within 1-2 weeks).

The plasma tHcy-lowering effect of betaine was quantitatively similar in both genders except in men after the first betaine dose, which resulted in an increase of $4.3 \%$ in plasma tHcy compared with the decrease of $6.6 \%$ in women (Fig. 2). Although the intake of folate from two dietary records during the first week indicated no significant change, plasma folate decreased in men in and women, possibly because they were asked to avoid foods particularly rich in folate.

Until recently it was believed that the intake of betaine from ordinary food is so low that plasma tHcy could not be affected by dietary means. Zeisel et al. (2003), however, analysed foods from the USA for betaine and estimated that significant amounts $(0.5-2.0 \mathrm{~g})$ of betaine may be attained from the diet, the main sources being wheat germ, spinach, beets and shrimps. Our preliminary estimate, based on the Finnish balance sheet supplemented with data from Zeisel et al. (2003), indicated a mean intake of $0.14 \mathrm{~g} / \mathrm{d}$; the intake calculated from the food records in the present study was $0.18 \mathrm{~g} / \mathrm{d}$ (ML Ovaskainen, personal communication). The sources of betaine (Zeisel et al. 2003) and folate (Alfthan et al. 2003) are different and because the metabolic pathways through which they lower homocysteine are not related, they can provide additive plasma tHcy-lowering effects.

The six subjects with an initial plasma tHcy value $>14 \mu \mathrm{mol} / \mathrm{l}$ benefited from betaine more than those with a normal tHcy at baseline. The other common feature of these six subjects was a low plasma folate (mean $6.8 \mathrm{nmol} / \mathrm{l}$ ). Thus, it seems that mildly hyperhomocysteinemic subjects benefit the most from additional betaine, as has been shown for individuals with the homozygous methylenetetrahydrofolate reductase TT genotype from folic acid supplements (Homocysteine Lowering Trialists' Collaboration 1998; Pullin et al. 2001; Alfthan et al. 2003).

Our pilot study showed that by dosing with $6 \mathrm{~g}$ betaine/d a steady-state of plasma tHcy was reached after $5 \mathrm{~d}$. Although respective data for folic acid are not available to our knowledge, we assumed in our present experiment that $7 \mathrm{~d}$ would suffice also for folic acid. A single dose of $400 \mu \mathrm{g}$ folic acid has been shown to keep plasma folate elevated for $6 \mathrm{~h}$ (Prinz-Langenohl et al. 1999). The acute effect of betaine on plasma tHcy is rapid. After a single dose of $6 \mathrm{~g}$ betaine, plasma tHcy decreased by about $10 \%$ after $1 \mathrm{~h}$ and stayed at this level for the remaining $24 \mathrm{~h}$ (U Schwab, personal communication). In the study by Olthof et al. (2003), the betaine dose was given two times per d, i.e. after breakfast and dinner. Our subjects were allowed to finish their drink during the day. Data simulated by Matthews et al. (2002) showed that multiple dosage seemed to improve the response only slightly compared with a single dose.

The sequential increasing dose study design was chosen because it allowed us to use a smaller number of subjects in a shorter time. As the dose increased, the carry-over effect was probably small.

In the present study we were not able to compare separately the effects of betaine and folic acid on plasma homocysteine. However, a relatively large dose of folic acid together with $6 \mathrm{~g}$ betaine contributed only slightly more to the lowering of plasma tHcy than betaine by itself. We chose to co-supplement betaine with only folic acid, as including pyridoxine and cyanocobalamin would probably have provided very little extra benefit (Ubbink et al. 1994). The intakes of pyridoxine, cyanocobalamin and riboflavin in our present subjects were adequate according to Finnish national recommendations (1998), but the intake of folate reached on average only 73 and $85 \%$ of the energy-adjusted recommendation $(36 \mu \mathrm{g} / \mathrm{MJ})$ for men and women respectively. Steenge et al. (2003) compared the relative effects of $6 \mathrm{~g}$ betaine or $800 \mu \mathrm{g}$ folic acid/d on plasma tHcy in mildly hyperhomocysteinemic subjects during a 6-week intervention. Betaine lowered plasma tHcy by $11 \%$ and folic acid by $18 \%$, but the difference was not statistically significant between treatments. In another study in chronic haemodialysis patients, van Guldener et al. (1999) compared the relative effect of $5 \mathrm{mg}$ folic acid supplementation with the combination $5 \mathrm{mg}$ folic acid $+4 \mathrm{~g}$ betaine/d for 12 weeks. Compared with folic acid, betaine did not have additional homocysteine-lowering effects.

In subjects with a poor response to folic acid, a combined dose including betaine and folic acid may prove effective, since the two compounds are metabolized by different organs (betaine in the liver and kidney, folate remethylation in most cells). The product of the transmethylation of homocysteine is methionine. Long-term treatment of homocystinuric patients with betaine causes increased plasma methionine concentrations, which have remained elevated with no adverse effects (Wilcken \& Wilcken, 1997).

We conclude that 3 or $6 \mathrm{~g}$ betaine/d lowers plasma tHcy significantly in healthy men and women. 


\section{References}

Alfthan G, Laurinen M, Valsta L, Pastinen T \& Aro A (2003) Plasma folate, folate intake and homocysteine status in a random Finnish population. Eur J Clin Nutr 57, 81-88.

Bell GI, Karam JH \& Rutter WJ (1981) Polymorphic DNA region adjacent to the $5^{\prime}$ end of the human insulin gene. Proc Natl Acad Sci 78, 5759-5763.

Brouwer IA, van Dusseldorp M, Thomas CMG, Duran M, Hautvast JGAJ, Eskes TKAB \& Steegers-Theunissen RPM (1999) Low-dose folic acid supplementation decreases plasma homocysteine concentrations: a randomized trial. Am J Clin Nutr 69, 99-104.

Brouwer IA, Verhoef P \& Urgert R (2000) Betaine supplementation and plasma homocysteine in healthy volunteers. Arch Int Med 160, 2546-2547.

Eikelboom JW, Lonn E, Genest J, Hankey G \& Yusuf S (1999) Homocysteine and cardiovascular disease: a critical review of the epidemiological evidence. Ann Int Med 131, 363-375.

Finnish Nutritional Recommendations (1998) www.mmm.fi/ravitsemusneuvoltelukunta/nutrec98.pdf (The recommendations are in English).

Gudnason V, Stansbie D, Scott J, Bowron A, Nicaud V Humphries S, on behalf of the EARS group (1998) C677T (thermolabile alanine/valine) polymorphism in methylenetetrahydrofolate reductase (MTHFR): its frequency and impact on plasma homocysteine concentration in different European populations. Atherosclerosis 136, 347-354.

Homocysteine Lowering Trialists' Collaboration (1998) Lowering blood homocysteine with folic acid based supplements: metaanalysis of randomised trials. Br Med J 316, 894-898.

Knekt P, Reunanen A, Alfthan G, Heliövaara M, Rissanen H, Marniemi J \& Aromaa A (2001) Hyperhomocysteinemia - a risk factor or a consequence of coronary heart disease? Arch Int Med 161, 1589-1594.

Laryea MD, Steinhagen F, Pawliczek S \& Wendel U (1998) Simple method for the routine determination of betaine and N,N dimethylglycine in blood and urine. Clin Chem 44, 1937-1941.

Matthews A, Johnson TN, Rostami-Hodjegan A, Chakrapani A, Wraith JE, Moat SJ, Bonham JR \& Tucker JT (2002) An indirect response model of homocysteine supression by betaine:optimising the dosage regimen of betaine in homocystinuria. $\mathrm{BrJ}$ Clin Pharmacol 54, 140-146.

Möller J, Rasmussen K \& Christensen L (1999) External quality assessment of methylmalonic and total homocysteine. Clin Chem 45, 1536-1542.

Mudd SH, Levy HL \& Skovby F (1995) Disorders of transsulfuration. In The Metabolic and Molecular Basis of Inherited Disease, 7th ed. pp. 1279-1327 [CR Scriver, AL Beaudet, WS Sly and D Valle, editors]. New York: McGraw-Hill.

Olthof MR, van Vliet T, Boelsma E \& Verhoef P (2003) Low dose betaine supplementation leads to immediate and long term lowering of plasma homocysteine in healthy men and women. J Nutr 133, 4135-4138.

Ovaskainen ML (2001) Fineli ${ }^{\circledR}$ Elintarvikkeiden Koostumustietopankki (National Food Composition Database). www.ktl.fi/ fineli (in Finnish).

Prinz-Langenohl R, Brönstrup A, Thorand B, Hages M \& Pietrzik K (1999) Availability of food folate in humans. J Nutr 29, 913-916.

Pullin CH, Ashfield-Watt PAL, Burr ML, et al. (2001) Optimization of dietary folate or low-dose folic acid supplements lower homocysteine but do not enhance endothelial function in healthy adults, irrespective of the methylenetetrahydrofolate reductase (C677T) genotype. $J$ Am Coll Cardiol 38, $1799-1805$.

Schwab U, Törrönen A, Toppinen L, Alfthan G, Aro A \& Uusitupa M (2002) Betaine supplementation with a low calorie diet decreases plasma homocysteine concentrations but does not affect body weight, body composition, resting energy expenditure or serum lipid concentrations. Am J Clin Nutr 76, 961-967.

Schwahn BC, Hafner D, Hohfeld T, Balkenhol N, Laryea MD \& Wendel U (2003) Pharmacokinetics of oral betaine in healthy subjects and patients with homocystinuria. Br J Clin Pharmacol 55, 6-13.

Steenge GR, Verhoef P \& Katan MB (2003) Betaine supplementation lowers plasma homocysteine in healthy men and women. J Nutr 133, 1291-1295.

Ubbink JB, Vermaak WJH \& Bissbort S (1991) Rapid high-performance liquid chromatography assay for total homocysteine levels in human serum. J Chromatogr 565, 441-446.

Ubbink JB, Vermaak WJH, van der Merwe A, Becker PJ, Delport R \& Potgieter HC (1994) Vitamin requirements for the treatment of hyperhomocysteinemia in humans. $J$ Nutr $\mathbf{1 2 4}$, $1927-1933$

Van Guldener C, Janssen MJF, deMeer K, Donker AJM \& Stehouwer CDA (1999) Effect of folic acid and betaine on fasting and postmethionine-loading plasma homocysteine and methionine levels in chronic haemodialysis patients. $J$ Int Med 245, 175-183.

Wilcken DEL \& Wilcken B (1997) The natural history of vascular disease in homocystinuria and effects of treatment. J Inherit Metab Dis 20, 295-300.

Wilcken DEL, Wilcken B, Dudman NPB \& Tyrrell PA (1983) Homocystinuria - the effects of betaine in the treatment of patients not responsive to pyridoxine. $N$ Engl J Med 309, 448-453.

Zeisel SH, Mar MH, Howe JC \& Holden JM (2003) Concentrations of choline-containing compounds and betaine in common foods. $J$ Nutr 133, 1302-1307. 